\title{
EVALUATION OF SMALL TREE AND SHRUB PLANTINGS ON RECLAIMED SURFACE MINES IN WEST VIRGINIA ${ }^{1}$
}

\author{
A. Monteleone ${ }^{2}$, J. Skousen, L. McDonald, J. Shuler, J. Pomp, M. French, and R. Williams
}

\begin{abstract}
Hundreds of hectares of mined land are reclaimed annually in Appalachia and planted with commercially-valuable hardwood tree species for forestry post-mining land uses. Establishment and growth of fruit and nutproducing tree and shrub species for wildlife habitat post-mining land uses have not been extensively studied on surface mines. Though these species are not planted as part of forestry reclamation, they are commonly found in forest ecosystems of WV and provide a food source for a variety of wildlife, insects, and microorganisms, all of which are important for maintaining a sustainable and functioning forest ecosystem. The objective of this study was to determine survival and growth of 20 species of nut and fruit-producing shrubs and small trees to evaluate their suitability for reclamation plantings. Seedlings were planted in graded overburden material in 2008 and 2010 on four reclaimed surface coal mines in WV. The selected sites were reclaimed using conventional methods. The experiment was a completely randomized block design with four replications per site. At each site, four blocks measuring $4,160 \mathrm{~m}^{2}$, two east-aspect and two westaspect, were established. Each block was comprised of 20 monoculture species plots, and within each plot 25 individuals of the selected species were planted on $2.4 \mathrm{~m} \times 2.4 \mathrm{~m}$ spacing. Survival and growth of these species were measured in one growing season after planting and again in 2015 to determine individual species survival and growth. The best performing species overall were Washington hawthorn (Crataegus phaenopyrum), black chokeberry (Aronia melanocarpa), nannyberry (Viburnum lentago), black cherry (Prunus serotina), gray dogwood (Cornus racemosa), and red mulberry (Morus rubra) in that order with survival ranging from 62 to $43 \%$ after five to seven growing seasons. These species survived and appeared healthy on most blocks. The poorest performing species ( $\leq 27 \%$ survival) in descending order were blueberry (Vaccinium corymbosum L.), flowering dogwood (Cornus florida), and the worst performer being pawpaw (Asimina triloba) at only 9\% survival.
\end{abstract}

${ }^{1}$ Oral paper presented at the 2016 National Meeting of the American Society of Mining and Reclamation, Spokane, WA Reclaiming the West June 4-9, 2016.

2 Alexis Monteleone (Graduate Student), Jeff Skousen (Professor), Louis McDonald (Professor), Jamie Schuler (Asst. Professor), West Virginia University, Morgantown, WV 26505; Jonathan Pomp (Senior Forester), Forestry, Carbon, and GHG Services Division, Morgantown, WV 26501; Michael French (Director of Operations), Green Forests Work, Lexington, KY 40546; and Rick Williams (Reclamation Contractor), Williams Forestry and Associates, Calhoun, GA 30701.

DOI: http://doi.org/10.21000/JASMR17010034 


\section{Introduction}

West Virginia and the Appalachian region has over 100 minable coal seams (Bise, 2013), and because of the abundance of coal the region has had a long history with coal mining. The coal mining industry in the region has been a dynamic one. During the early 1900s, coal mining was primarily by underground mining methods, a change to surface mining happened from 1950 to 2000, and is now shifting again back to underground mining. Just as the coal extraction process has changed over time, so has the idea of reclamation. Early reclamation efforts only reshaped the land with little or no emphasis on revegetation of the disturbed area. However, with the passage of strict environmental laws, today the focus is on restoring the site back to its original productivity or something better.

Historically, more coal was harvested using underground or shallow surface mining methods. Due to smaller equipment size, particularly for surface mines, technology restricted surface mining to shallow coal seams (Gorman et al., 2001). Reclamation was not a federal requirement, but some states, like West Virginia, enacted legislation in 1939 and the early 1940s (Bowling et al., 1987; Plass, 2000). Enforcement of this legislation was not carried out well and as a result large areas of unreclaimed land were left after mining. This early reclamation focused mainly on reshaping the land and consisted of placing the overburden materials back into the excavated area and smoothing, grading, and compacting the overburden area. There was little to no emphasis on revegetation and if anything was planted, the trees most commonly planted were black locust (Robinia pseudoacacia) and pine (Pinus spp.) species (Vogel et al., 1981).

Tree growth on reclaimed mine sites has been studied since the 1930s due to interest in trying to re-establish the diverse eastern deciduous Appalachian forest ecosystem on disturbed sites. This forest ecosystem is regarded as the most diverse non-tropical forest ecosystem in the world, and performs important ecosystem services like controlling water quality and quantity, providing wildlife habitat, sequestering carbon, and producing wood and fibers (Burger, 1999). The state of West Virginia is 78 percent forested, and the reclamation of disturbed lands to forest sites is important to maintain ecological stability in our region.

With World War II came the emergence of machinery capable of extending surface mining to deeper depths and across larger landscape areas. Using this new machinery, the technology of surface mining developed and coal seams previously too deep or thin to access were now mineable. 
As more area of land became disturbed, public concern over the disturbed area heightened. As a result, the Surface Mining Control and Reclamation Act of 1977 (SMCRA) was passed and gave federal-to-state oversight for active mines for reclamation, and provided funds for an abandoned mine land reclamation program (Skousen and Zipper, 2014). SMCRA required that coal mine operators submit a permit, which served as a contract between them and the regulatory authority. This permit outlined all practices that were to be carried out on the mine and it included plans for the post-mining area. This designation of a post-mining land use served as a reclamation goal for the mine operator, and different post-mining land uses required different reclamation practices.

The goals outlined in SMCRA were to minimize the adverse effects of coal mining on disturbed land including water quality and quantity, sediment quality and quantity, and vegetative cover (Burger, 1999). Reductions in pollution and runoff have been two goals of reclamation, but the methods used to achieve reductions have drastically changed over time as knowledge has increased. After the passage of SMCRA, between the late 1980s and 1990s, mine operators were encouraged to excessively grade and smooth the overburden material and to establish a fastgrowing herbaceous ground cover (Torbert and Burger, 2000). These practices were detrimental to tree growth on reclaimed mine sites because grading of the overburden created a compacted rooting medium impenetrable by plant roots, and the aggressive herbaceous cover mixes competed with woody growth. As a result of this compaction and competition, most mines completed during this era were reclaimed to hay/pasture post-mining land uses because the land was not conducive to tree growth. This created another reclamation problem not previously seen before. The grasslands created were composed of highly aggressive agricultural forage species and were not generally managed or harvested for hay or feed, and therefore remained largely as a monoculture restricting the recruitment and colonization of native species, particularly trees. In this condition, the vegetation community fell into a state of ecological arrest where it was unable to progress past the point of being dominated by fescue grasses, and some invasive shrubs. Since 2005 surface grading has become more restricted, so less compacted soil surfaces are created. The planting of herbaceous species has also been changed to less-competitive species that are often native in origin and seeded at lower rates (Burger et al., 2005).

The Appalachian Regional Reforestation Initiative (ARRI) is a cooperative effort by the states of the Appalachian Region with the United States Department of Interior (USDI) Office of Surface Mining (OSM) to encourage restoration of high quality forests on reclaimed coal mines in the 
eastern USA (Angel et al., 2005). ARRI encourages the use of the Forestry Reclamation Approach (FRA) to create successful reforestation plantings and combat the usual challenges, soil depth and compaction, on reclaimed coal mines. The FRA consists of 5 steps:

1. Create a suitable rooting medium compatible with tree growth at least 4 feet deep and made up of topsoil, weathered sandstone, and/or the best material available.

2. Do not compact the growing medium with heavy grading, and instead only loosely grade the topsoil or topsoil substitute established in step 1.

3. Use a tree-compatible herbaceous cover that will not outcompete woody growth.

4. Plant two tree types: early successional species for wildlife and soil stability and commercially-valuable crop trees.

5. Use proper tree planting techniques.

The intent of FRA reclamation is to develop a forest plant community with all the ecological components necessary for maximizing multiple uses of the reclaimed area. It has been developed by consensus of a broad group of academic researchers, industry, and regulatory personnel as the most suitable way to establish commercially-valuable tree species on mined sites and to assure their rapid growth and development. Once the non-compacted soil or soil substitute is created, using the FRA paired with the tree-compatible herbaceous cover provides the opportunity for recruitment and colonization of native and volunteer species from surrounding forests to re-inhabit the site (Zipper et al., 2013). Foresters know that initially planting a diversity of tree types will more rapidly introduce species that will enhance the functional and structural diversity of the ecosystem. The non-commercial species that should be planted with the commercially-valuable crop trees in Step 4 are still not clearly defined, and will become more evident with more extensive field studies. These non-commercial species largely belong to the early-successional group, which do not dominate mature forest canopies but instead are a part of stand initiation or cohort reestablishment in forest succession. These early-successional ecosystems are very species-diverse due to the amount of growth resources available post-disturbance that were not available predisturbance (Swanson et al., 2010). A diverse plant community enhances the wildlife habitat potential, recreational, aesthetic, and productive value of the reclaimed land. Diversity of plant morphologies increase structural richness and contributes to both horizontal and vertical heterogeneity (Swanson et al., 2010). 
The overall goal of land reclamation is to return the mining-disturbed area to a condition equal to or better than the land's original condition before mining (Skousen and Zipper, 2014). One way to do this is to plant trees and to return the land to a forest post-mining land use (MacDonald et al., 2015; Zipper et al., 2011, 2013). Early-successional trees and shrubs are said to be ecological enhancers that provide many benefits to the ecosystem (Alday, 2014). The objective of this study was to determine potential species that could be planted during reclamation and to evaluate their growth when planted on surface mines in West Virginia. To meet this objective, we determined the survival and growth of 20 native small tree and shrub species that were planted on four reclaimed surface coal mined sites five to seven years ago. The goal was to identify which species survived and performed well by evaluating their growth over time.

\section{Materials and Methods}

$\underline{\text { Sites, Experimental Design, and Sampling Procedures }}$

Williams Forestry, a commercial tree planter, established native shrub and small tree plantings in 2008 and 2010 on four surface mines in West Virginia. The four sites (and their planting date) were Elk Run (2008), Hobet (2008), Birch River (2010), and Fola (2010). Both sites, Elk Run and Hobet, are located in the Appalachian Plateau physiographic region in Boone County of southwestern West Virginia. The four blocks on each site were separated into two east-facing and two west-facing blocks. The Elk Run mine is located in central Boone County, WV and covers roughly 5,000 acres. The mine is operated by Alpha Natural Resources. The tree and shrub planting block locations at Elk Run are located at approximately $38^{\circ} 04^{\prime} 20^{\prime \prime} \mathrm{N}, 81^{\circ} 43^{\prime} 27^{\prime \prime} \mathrm{W}$. The Hobet mine near Madison, WV covers approximately 13,000 acres in Boone and Lincoln counties. The Hobet block locations are located at approximately $38^{\circ} 07^{\prime} 38.76^{\prime \prime} \mathrm{N}, 81^{\circ} 52^{\prime} 37.83^{\prime \prime}$ W. The sites established in 2010, Birch River and Fola, are also located in the Appalachian Plateau physiographic region of West Virginia. The two east-facing Birch River blocks are located at approximately $38^{\circ} 26^{\prime} 08.45^{\prime \prime} \mathrm{N}, 80^{\circ} 37^{\prime} 05.74^{\prime \prime} \mathrm{W}$, and the two west-facing Birch River blocks are located at approximately $38^{\circ} 27^{\prime} 21.95^{\prime \prime} \mathrm{N}, 80^{\circ} 36^{\prime} 36.96^{\prime \prime} \mathrm{W}$. Fola is a large mine that covers approximately 7,000 acres in Clay County, WV. The research blocks are located at approximately $38^{\circ} 35^{\prime} 24.66^{\prime \prime} \mathrm{N}, 81^{\circ} 08^{\prime} 94.19^{\prime \prime} \mathrm{W}$. The experiment is a completely randomized block design with four replications at each site. At each site, four blocks (replications), each measuring $0.42 \mathrm{ha}$, were established (see Fig. 1 for an example of the design at Birch River). Two blocks are located on east-facing aspects, while the other two blocks are oriented on west-facing aspects. In each block, 
plots measuring $208 \mathrm{~m}^{2}$ were delineated. In each plot, one of 20 small tree or shrub species were randomly chosen and planted with 25 individuals of each species on a $2.4 \mathrm{~m}$ x $2.4 \mathrm{~m}$ spacing (Table 1). Williams Forestry conducted survival and height measurements a few months after transplanting in each of the years of planting. Trees were planted in March and monitoring was conducted in September of the year of planting (Elk Run and Hobet, 2008; Birch River and Fola, 2010).

There were two changes in the experimental design during this experiment. The first change that occurred was the loss of two blocks at Fola, which we couldn't find due to the massive overgrowth of invasive species in the area including autumn olive (Elaeagnus umbellate L.), sericea lespedeza (Lespedeza cuneata L.), and bicolor lespedeza (Lespedeza bicolor L.). The other change occurred due to differing number of species planted on each block among the planting years. In 2008, only 19 tree and shrub species were planted, whereas the 2010 plantings included hazelnut (Corylus avellana L.). Elk Run and Hobet (2008 plantings) do not have data for hazelnut.

Block 7 East

\begin{tabular}{|c|c|c|c|c|}
\hline 14 & 1 & 18 & 2 & 3 \\
\hline 4 & 20 & 15 & 13 & 19 \\
\hline 11 & 7 & 9 & 6 & 12 \\
\hline 17 & 10 & 8 & 16 & 5 \\
\hline
\end{tabular}

Block 7 West

\begin{tabular}{|c|c|c|c|c|}
\hline 10 & 5 & 9 & 4 & 18 \\
\hline 7 & 11 & 14 & 3 & 13 \\
\hline 2 & 19 & 8 & 16 & 15 \\
\hline 1 & 6 & 20 & 17 & 12 \\
\hline
\end{tabular}

Block 8 East

\begin{tabular}{|c|c|c|c|c|}
\hline 5 & 16 & 18 & 11 & 20 \\
\hline 4 & 1 & 8 & 10 & 7 \\
\hline 15 & 14 & 17 & 19 & 12 \\
\hline 9 & 3 & 6 & 13 & 2 \\
\hline
\end{tabular}

Block 8

West

\begin{tabular}{|c|c|c|c|c|}
\hline 7 & 11 & 17 & 14 & 8 \\
\hline 2 & 10 & 13 & 12 & 4 \\
\hline 18 & 9 & 19 & 3 & 16 \\
\hline 6 & 1 & 5 & 20 & 15 \\
\hline
\end{tabular}

Figure 1. The randomized complete block design used at Birch River. Similar blocks were placed at the other sites. Numbers within blocks represent different tree and shrub species (see Table 1). Twenty-five individuals of each species were planted in each plot on $2.4 \mathrm{x}$ $2.4 \mathrm{~m}$ spacing. 
Table 1. List of small tree and shrub species used in this study. Growth forms were determined using the USDA Plants Database.

\begin{tabular}{|c|c|c|c|}
\hline $\begin{array}{l}\text { GROWTH } \\
\text { FORM }\end{array}$ & COMMON NAME & SCIENTIFIC NAME & ID ON FIG. 1 \\
\hline \multirow[t]{14}{*}{ TREES } & American Crabapple & Malus coronaria L. & 9 \\
\hline & Black Cherry & Prunus serotina Ehrh. & 11 \\
\hline & Choke Cherry & Prunus virginiana L. & 17 \\
\hline & Common Apple & Malus pumila Mill. & 18 \\
\hline & Common Pear & Pyrus communis $\mathrm{L}$. & 13 \\
\hline & Eastern Redbud & Cercis Canadensis L. & 4 \\
\hline & Elderberry & Sambucus Canadensis L. & 1 \\
\hline & Flowering Dogwood & Cornus florida $\mathrm{L}$. & 19 \\
\hline & Pawpaw & Asimina triloba $\mathrm{L}$. & 7 \\
\hline & Persimmon & Diospyros virginiana L. f. & 6 \\
\hline & Serviceberry & $\begin{array}{l}\text { Amelanchier arborea Michx. } \\
\text { f. Fernald }\end{array}$ & 15 \\
\hline & Red Mulberry & Morus rubra L. & 8 \\
\hline & Washington Hawthorn & Crataegus phaenopyrum L. f. & 2 \\
\hline & Wild Plum & Prunus Americana Marshall & 3 \\
\hline \multirow[t]{6}{*}{ SHRUBS } & Black Chokeberry & Aronia melanocarpa Michx. & 14 \\
\hline & Blueberry & Vaccinium corymbosum $\mathrm{L}$. & 12 \\
\hline & Gray Dogwood & Cornus racemose Lam. & 5 \\
\hline & Hazelnut & Corylus avellana $\mathrm{L}$. & 20 \\
\hline & Highbush Cranberry & Viburnum trilobum $\mathrm{L}$. & 10 \\
\hline & Nannyberry & Viburnum lentago L. & 16 \\
\hline
\end{tabular}

Sampling was conducted in the summer of 2015 and involved measuring the height, crown cover or stem diameter, and vigor of each individual shrub or tree found in the plots. Height for each plant was estimated with a 3 -meter pole with height markings at 0.25 -m increments. Either diameter of the main stem or crown cover was measured depending on the growth form of the plant (one basal stem vs. many stems). For stem diameter, measurements were taken at approximately $2.5 \mathrm{~cm}$ above the ground surface using calipers. For crown cover, measurements of the widest and shortest area of crown spread were made using a tape measure, and the average crown was recorded.

Slope gradient was recorded at the center of each block using a clinometer. While slope varied across the plots on each site, average block slope was also calculated. At three random locations within each plot, a soil sample was collected to a depth of $15 \mathrm{~cm}$ and these three samples were composited into one sample for each plot. Therefore, 20 soil samples were composited for each block and each site had four soil samples for analysis. Samples were dried, weighed, and sieved 
into coarse and fine fractions (2-mm sieve). The fine soil fraction $(\leq 2 \mathrm{~mm})$ was analyzed for chemical properties including soil $\mathrm{pH}$ and soluble salts (as electrical conductivity). Means were calculated for fines percentage or the percentage of material finer than the 2-mm sieve, $\mathrm{pH}$, and electrical conductivity (EC) or the measure of salinity for each site.

The data on survival and height for each species were analyzed by ANOVA to determine significant differences among sites and aspects using the Statistical Analysis System (SAS, Inc., 2011) and R language (R Development Core Team, 2016). Soil properties were also analyzed to determine significant differences among sites. Means for survival and height across sites were considered significant when the p-value was less than 0.05. Differences among sites were separated with Tukey's Honestly Significant Difference test.

\section{$\underline{\text { Results and Discussion }}$}

$\underline{\text { Shrub and Tree Survival and Growth }}$

Some species experienced extensive mortality within the first year while others survived very well in their first growing season (Tables 2 and 3).

Table 2. Survival of shrub species on all four sites one growing season after planting (Elk Run and Hobet, 2008; Birch River and Fola, 2010).

\begin{tabular}{|l|c|c|c|c|c|}
\hline & \multicolumn{4}{|c|}{ Sites } & \\
\hline Shrub Species & Elk Run & Hobet & Birch River & Fola & Average \\
\hline & -------------------- & 90 \\
\hline Black Chokeberry & $98 \mathrm{a}^{1}$ & $64 \mathrm{~b}$ & $99 \mathrm{a}$ & $100 \mathrm{a}$ & 90 \\
\hline Blueberry & $96 \mathrm{a}$ & $98 \mathrm{a}$ & $52 \mathrm{~b}$ & $22 \mathrm{c}$ & 67 \\
\hline Gray Dogwood & $86 \mathrm{a}$ & $6 \mathrm{~b}$ & $98 \mathrm{a}$ & $86 \mathrm{a}$ & 69 \\
\hline Hazelnut & N/A & N/A & 97 & 86 & 92 \\
\hline Highbush Cranberry & 88 & 90 & 84 & 73 & 73 \\
\hline Nannyberry & $93 \mathrm{a}$ & $8 \mathrm{~b}$ & $72 \mathrm{a}$ & $73 \mathrm{a}$ & 80 \\
\hline & & & & & \\
\hline Average Survival & $77 \mathrm{a}$ & $56 \mathrm{a}$ & $84 \mathrm{a}$ & $73 \mathrm{a}$ & 79 \\
\hline
\end{tabular}

${ }^{1}$ Means for species survival across sites (within rows) with the same letter are not significantly different within rows at $\mathrm{p} \leq 0.05$. Where there are no letters, no significant difference in survival across sites. 
Table 3. Survival of tree species on all four sites one growing season after planting (Elk Run and Hobet, 2008; Birch River and Fola, 2010).

\begin{tabular}{|c|c|c|c|c|c|}
\hline \multirow[b]{2}{*}{ Tree Species } & \multicolumn{4}{|c|}{ Sites } & \\
\hline & Elk Run & Hobet & Birch River & Fola & Average \\
\hline & \multicolumn{5}{|c|}{ 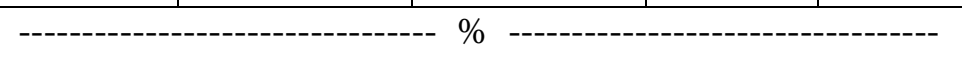 } \\
\hline American Crabapple & $68^{1}$ & 61 & 57 & 50 & 51 \\
\hline Black Cherry & $87 \mathrm{ab}$ & $64 \mathrm{~b}$ & $99 \mathrm{a}$ & $84 \mathrm{ab}$ & 84 \\
\hline Choke Cherry & 100 & 85 & 93 & 82 & 90 \\
\hline Common Apple & $92 \mathrm{a}$ & $76 b$ & $100 \mathrm{a}$ & $92 \mathrm{a}$ & 85 \\
\hline Common Pear & $62 b$ & $27 \mathrm{c}$ & $97 \mathrm{a}$ & $94 a$ & 70 \\
\hline Eastern Redbud & $91 \mathrm{a}$ & $72 b$ & $98 \mathrm{a}$ & $91 \mathrm{a}$ & 79 \\
\hline Elderberry & 43 & 68 & 40 & 68 & 55 \\
\hline Flowering Dogwood & $9 \mathrm{c}$ & $15 \mathrm{c}$ & $92 \mathrm{a}$ & $67 \mathrm{~b}$ & 41 \\
\hline Pawpaw & $86 a$ & $48 b$ & $89 a$ & $62 \mathrm{ab}$ & 71 \\
\hline Persimmon & $97 \mathrm{a}$ & $83 a$ & $100 \mathrm{a}$ & $77 \mathrm{a}$ & 79 \\
\hline Serviceberry & $87 a$ & $96 a$ & $90 \mathrm{a}$ & $57 \mathrm{~b}$ & 83 \\
\hline Red Mulberry & $90 \mathrm{a}$ & $21 b$ & $97 \mathrm{a}$ & $90 \mathrm{a}$ & 75 \\
\hline Washington Hawthorn & $93 a$ & $64 b$ & $98 \mathrm{a}$ & $98 \mathrm{a}$ & 88 \\
\hline Wild Plum & 86 & 73 & 98 & 98 & 81 \\
\hline Average Survival & $77 \mathrm{a}$ & $64 b$ & $88 \mathrm{a}$ & $78 \mathrm{a}$ & 74 \\
\hline
\end{tabular}

${ }^{1}$ Means for species survival across sites (within rows) with the same letter are not significantly different at $\mathrm{p} \leq 0.05$. Where there are no letters, no significant difference in survival across sites.

Survival percentages varied between species, across sites, and between the two growth forms, shrubs and trees. Birch River had the highest average percent survival overall for both shrubs $(84 \%)$ and trees $(88 \%)$, but these survival values were not significantly different from Elk Run and Fola. However, all three sites were significantly higher in survival than Hobet (64\%) across all the species. The best performing species after the first year with better than $90 \%$ average survival across sites were hazelnut (92\%), black chokeberry (90\%), and choke cherry (90\%). The species with less than $60 \%$ average survival after the first year were American crabapple (51\%), elderberry (55\%), and flowering dogwood (41\%). Some species survived poorly at some sites. For example, $50 \%$ or greater died of elderberry and flowering dogwood at Elk Run; common pear, gray dogwood, red mulberry, and flowering dogwood at Hobet; elderberry at Birch River; and eastern redbud and gray dogwood at Fola within the first season of growth on the mine sites. The reasons for poor survival within the first growing season could be due to poor planting stock, site and soil conditions, or some other factor such as rainfall or temperature during the growing season. 
Weather conditions experienced by the plants in their year of establishment may have greatly influenced survival. In this study, Elk Run and Hobet were planted in 2008, while Birch River and Fola were planted in 2010. The weather in the spring of 2008, the time of establishment, was described as normal for the season and state (NOAA, 2008). The summer of 2008 was warmer than normal for the country, but West Virginia experienced temperatures below normal. Fall of 2008 was described as cooler than normal in West Virginia, and the winter of 2008 was described as near normal for West Virginia. Rainfall received in the year 2008 was considered to be above normal in the spring, near normal in the summer, and below normal in the fall (NOAA, 2008). The sites planted in the spring of 2010 experienced a much warmer than normal spring with normal precipitation (NOAA, 2010). The summer of 2010 was warmer than normal with a normal amount of precipitation. The fall of 2010 was hotter than average for West Virginia, while the amount of precipitation received during that time was below normal (NOAA, 2010). Stem girdling by rodents and browsing by wildlife could also have had a negative effect on survival. On the other hand, some species survived overall very well and had high survival rates across all sites. Choke cherry had the highest and most consistent survival across sites after the first growing season.

Survival for each species on each site was also compared. Black chokeberry, gray dogwood, and nannyberry had significantly better survival at Elk River, Birch River, and Fola than at Hobet. Blueberry survival was higher on Elk Run and Hobet than on Birch River and Fola. For the tree species, we found similar results as the shrubs, with Hobet often having lower survival than the other sites for several of the species.

Average height measurements after the first growing season were undoubtedly linked to the size of plants at transplanting (Tables 4 and 5). Without any other knowledge of the height of the planted stock, growth during the first growing season cannot be determined. However, past experience with growth of woody plants on mine sites has demonstrated little to no growth during the first growing season (Burger and Fannon, 2009; Dallaire and Skousen, 2015; Emerson et al., 2009), as roots become acclimated and established in the soil medium. For the shrubs, black chokeberry seedlings were significantly higher in height at Fola than the other three sites, but no other differences were found. For the trees, 11 of the 13 species showed significant differences in height across sites after the first growing season. Again, this difference is mostly a reflection of different-sized planting stock. 
Table 4. Height of all shrub species on all four sites after one growing season after planting (Elk Run and Hobet, 2008; Birch River and Fola, 2010).

\begin{tabular}{|c|c|c|c|c|c|}
\hline \multirow[b]{2}{*}{ Shrub Species } & \multicolumn{4}{|c|}{ Sites } & \\
\hline & Elk Run & Hobet & Birch River & Fola & Average \\
\hline & \multicolumn{5}{|c|}{------------------------------- cm ---------------------------- } \\
\hline Black Chokeberry & $36 b^{1}$ & $34 b$ & $33 b$ & $60 \mathrm{a}$ & 41 \\
\hline Blueberry & 21 & 22 & 21 & 18 & 21 \\
\hline Gray Dogwood & 41 & 38 & 43 & 47 & 42 \\
\hline Hazelnut & N/A & N/A & 36 & 34 & 35 \\
\hline Highbush Cranberry & 37 & 39 & 30 & 32 & 35 \\
\hline Nannyberry & 37 & 39 & 48 & 35 & 40 \\
\hline
\end{tabular}

${ }^{1}$ Means for species survival across sites (within rows) with the same letter are not significantly different within rows at $\mathrm{p} \leq 0.05$. Where there are no letters, no significant difference in height across sites.

Table 5. Height of all tree species on all four sites after one growing season after planting (Elk Run and Hobet, 2008; Birch River and Fola 2010).

\begin{tabular}{|c|c|c|c|c|c|}
\hline \multirow[b]{2}{*}{ Tree Species } & \multicolumn{4}{|c|}{ Sites } & \multirow[b]{2}{*}{ Average } \\
\hline & Elk Run & Hobet & Birch River & Fola & \\
\hline & \multicolumn{5}{|c|}{ 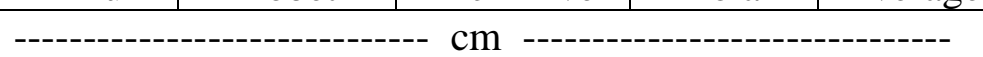 } \\
\hline American Crabapple & $22 a b^{1}$ & $19 b$ & $17 \mathrm{~b}$ & $29 \mathrm{a}$ & 22 \\
\hline Black Cherry & $75 \mathrm{a}$ & $81 \mathrm{a}$ & $51 b$ & $46 b$ & 63 \\
\hline Choke Cherry & 36 & 42 & 34 & 39 & 38 \\
\hline Common Apple & $37 \mathrm{~b}$ & $29 b$ & $65 \mathrm{a}$ & $52 \mathrm{ab}$ & 46 \\
\hline Common Pear & 22 & 30 & 36 & 50 & 34 \\
\hline Eastern Redbud & 55 & 38 & 43 & 43 & 45 \\
\hline Elderberry & $19 \mathrm{ab}$ & $28 \mathrm{a}$ & $10 \mathrm{bc}$ & $7 \mathrm{c}$ & 16 \\
\hline Flowering Dogwood & $60 \mathrm{a}$ & $42 \mathrm{ab}$ & $21 b$ & $24 b$ & 37 \\
\hline Pawpaw & $33 a$ & $42 \mathrm{a}$ & $40 \mathrm{a}$ & $15 b$ & 32 \\
\hline Persimmon & $37 \mathrm{a}$ & $39 a$ & $40 \mathrm{a}$ & $19 \mathrm{~b}$ & 34 \\
\hline Serviceberry & $37 \mathrm{a}$ & $38 \mathrm{a}$ & $30 \mathrm{a}$ & $12 \mathrm{~b}$ & 29 \\
\hline Red Mulberry & $54 a$ & $19 \mathrm{a}$ & $33 \mathrm{ab}$ & $28 \mathrm{ab}$ & 34 \\
\hline Washington Hawthorn & $46 b$ & $49 b$ & $78 \mathrm{a}$ & $50 \mathrm{~b}$ & 56 \\
\hline Wild Plum & $37 \mathrm{~b}$ & $38 b$ & $48 \mathrm{a}$ & $48 \mathrm{a}$ & 42 \\
\hline
\end{tabular}

${ }^{1}$ Means for species survival with the same letter are not significantly different (within rows) at $\mathrm{p} \leq 0.05$. Where there are no letters, no significant difference in height across sites.

Lastly, the effect of aspect was tested for each species' survival. For the shrub species, no significant differences were found for survival on east- vs west-facing aspects, although it was clear from the data that the east-facing aspect was always lower in survival than the west-facing aspects (Table 6). For trees, only one, American crabapple, was significantly lower in survival on the east- $(48 \%)$ vs the west- $(78 \%)$ aspect. But again, survival on east-facing slopes was generally lower than those on the west-facing aspects (Table 7). 
Table 6. Survival of all shrub species on all four sites after one growing season after planting on east and west aspects (Elk Run and Hobet, 2008; Birch River and Fola, 2010).

\begin{tabular}{|l|c|c|c|}
\hline & \multicolumn{2}{|c|}{ Aspect } & \\
\hline Shrub Species & East & West & Average \\
\hline & ----------- \\
\hline Black Chokeberry & $87^{1}$ & 98 & 93 \\
\hline Blueberry & 42 & 78 & 60 \\
\hline Gray Dogwood & 66 & 70 & 68 \\
\hline Hazelnut & 82 & 96 & 89 \\
\hline Highbush Cranberry & 69 & 84 & 77 \\
\hline Nannyberry & 72 & 90 & 81 \\
\hline & & & \\
\hline Average Survival & 69 & 86 & 78 \\
\hline
\end{tabular}

${ }^{1}$ Means for species survival with the same letter are not significantly different at $\mathrm{p} \leq 0.05$. Where there are no letters, no significant difference (within rows) in survival across aspects.

Table 7. Survival of all tree species on all four sites after one growing season after planting on east and west aspects (Elk Run and Hobet, 2008; Birch River and Fola, 2010).

\begin{tabular}{|c|c|c|c|}
\hline & \multicolumn{2}{|c|}{ Aspect } & \\
\hline \multirow[t]{2}{*}{ Tree Species } & East & West & Average \\
\hline & \multicolumn{3}{|c|}{------------ \% } \\
\hline American Crabapple & $48 b^{1}$ & $78 \mathrm{a}$ & 63 \\
\hline Black Cherry & 88 & 82 & 85 \\
\hline Choke Cherry & 83 & 91 & 87 \\
\hline Common Apple & 89 & 94 & 92 \\
\hline Common Pear & 72 & 67 & 69 \\
\hline Eastern Redbud & 96 & 78 & 87 \\
\hline Elderberry & 39 & 65 & 52 \\
\hline Flowering Dogwood & 38 & 45 & 42 \\
\hline Pawpaw & 64 & 73 & 69 \\
\hline Persimmon & 79 & 95 & 87 \\
\hline Serviceberry & 58 & 74 & 66 \\
\hline Red Mulberry & 75 & 78 & 77 \\
\hline Washington Hawthorn & 79 & 94 & 87 \\
\hline Wild Plum & 93 & 83 & 88 \\
\hline Average Survival & 71 & 78 & 75 \\
\hline
\end{tabular}

${ }^{1}$ Means for species survival with the same letter are not significantly different (within rows) at $\mathrm{p} \leq 0.05$. Where there are no letters, no significant difference in survival across aspects. 
During the summer of 2015, all trees and shrubs were sampled to determine survival and growth. This represented a total of 7,000 plants (500 plants per block for 14 blocks across all the sites). Two of the sites, Elk Run and Hobet, were planted in 2008 and therefore represented survival and growth after 7 years. Birch River and Fola were planted in 2010 and represented survival and growth after 5 years.

For average shrub survival across all species, Hobet had the lowest survival (28\%) compared to 45 to $56 \%$ for the other three sites (Table 8). Gray dogwood and nannyberry showed significantly lower survival at Hobet, while blueberry had significantly higher average survival at Hobet compared to the other three sites. The shrub species with the greatest overall survival across all sites was black chokeberry at 60\% (Table 8, Picture 1), but nannyberry, gray dogwood, and hazelnut had average survivals between 51 and 56\% (Pictures 2 and 3). Blueberry had the worst average survival (27\%), and plant specific site requirements could be responsible for its performance. Fola had no blueberry surviving after 5 years of growth, while Elk Run and Birch River had $18 \%$ survival for blueberry. It was the only shrub species with complete mortality at a mine site, Fola. Comparing species performance in Table 8 to Table 2 (the survival data after the first growing season), the survival percentages for each species dropped between 10 and 40\%; e.g., black chokeberry dropped from $90 \%$ average survival after the first year to $60 \%$ survival between 5 and 7 years later. Similarly, total survival across the species at each site dropped at the same amounts; e.g., Elk Run dropped from an average survival of $77 \%$ after the first year to $47 \%$ after 5 and 7 years.

Average tree survival greatly varied between individual species and across sites, and between shrubs and trees. Total shrub species survival was $48 \%$ compared to $39 \%$ for all trees on all sites (Table 9). Survival percentages for trees were much lower in 2015 than observed in the establishing year. On average, survival was less than 50\% total at all sites, and survival at Hobet was found to be significantly lower at $24 \%$ than at the other sites in the study. Washington hawthorn was the only species that had an average survival greater than 60\% (Pictures 4 to 6), with black cherry and gray dogwood having greater than 50\% survival. Poor performing species in the study included elderberry (30\%), flowering dogwood (10\%), and pawpaw (9\%). Pawpaw completely died out at two of the four sites, Elk Run and Hobet. 
Table 8. Survival of shrub species on all four sites in 2015 after 7 and 5 growing seasons after planting (Elk Run and Hobet planted in 2008; Birch River and Fola planted in 2010).

\begin{tabular}{|c|c|c|c|c|c|}
\hline & \multicolumn{4}{|c|}{ Sites } & \\
\hline \multirow[t]{2}{*}{ Shrub Species } & Elk Run & Hobet & Birch River & Fola & Average \\
\hline & \multicolumn{5}{|c|}{ 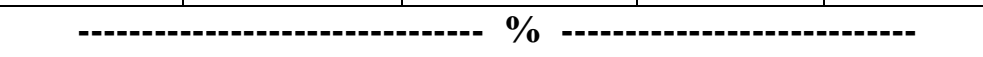 } \\
\hline Black Chokeberry & $45^{1}$ & 42 & 69 & 82 & 60 \\
\hline Blueberry & $18 \mathrm{~b}$ & $70 \mathrm{a}$ & $18 \mathrm{~b}$ & $\mathrm{Ob}$ & 27 \\
\hline Gray Dogwood & $84 \mathrm{a}$ & $3 \mathrm{c}$ & $50 \mathrm{~b}$ & $78 \mathrm{a}$ & 54 \\
\hline Hazelnut & N/A & N/A & 48 & 54 & 51 \\
\hline Highbush Cranberry & 52 & 24 & 43 & 49 & 42 \\
\hline Nannyberry & $84 a$ & $27 \mathrm{c}$ & $41 \mathrm{~b}$ & $74 \mathrm{ab}$ & 56 \\
\hline Average Survival & $47 a$ & $28 b$ & $45 a$ & $56 a$ & 48 \\
\hline
\end{tabular}

${ }^{1}$ Means for species survival with the same letter are not significantly different (within rows) at $\mathrm{p} \leq 0.05$. Where there are no letters, no significant difference in survival across sites.

Table 9. Survival of tree species on all four sites in 2015 after 7 and 5 growing seasons after planting (Elk Run and Hobet planted in 2008; Birch River and Fola planted in 2010).

\begin{tabular}{|c|c|c|c|c|c|}
\hline \multirow[b]{2}{*}{ Tree Species } & \multicolumn{4}{|c|}{ Sites } & \\
\hline & Elk Run & Hobet & Birch River & Fola & Average \\
\hline & \multicolumn{5}{|c|}{---------------------------------- \% --------------------------------- } \\
\hline American Crabapple & $57 a^{1}$ & $52 \mathrm{a}$ & $21 b$ & $34 \mathrm{ab}$ & 41 \\
\hline Black Cherry & 53 & 50 & 49 & 66 & 55 \\
\hline Choke Cherry & $73 \mathrm{a}$ & $26 b$ & $41 \mathrm{ab}$ & $26 b$ & 42 \\
\hline Common Apple & $24 \mathrm{~b}$ & $38 \mathrm{ab}$ & $57 \mathrm{a}$ & $54 \mathrm{a}$ & 43 \\
\hline Common Pear & $33 \mathrm{ab}$ & $20 \mathrm{~b}$ & $49 \mathrm{ab}$ & $64 a$ & 42 \\
\hline Eastern Redbud & $76 a$ & $16 b$ & $47 \mathrm{ab}$ & $56 a b$ & 49 \\
\hline Elderberry & $25 \mathrm{ab}$ & $14 \mathrm{~b}$ & $37 \mathrm{ab}$ & $44 a$ & 30 \\
\hline Flowering Dogwood & $6 b$ & $5 b$ & $24 \mathrm{a}$ & $6 b$ & 10 \\
\hline Pawpaw & $\mathrm{Ob}$ & $\mathrm{Ob}$ & $31 \mathrm{a}$ & $4 \mathrm{~b}$ & 9 \\
\hline Persimmon & $62 \mathrm{a}$ & $7 b$ & $41 \mathrm{ab}$ & $42 \mathrm{ab}$ & 38 \\
\hline Serviceberry & $76 a$ & $46 a b$ & $26 \mathrm{bc}$ & $14 \mathrm{c}$ & 41 \\
\hline Red Mulberry & $65 a$ & $3 b$ & $48 \mathrm{a}$ & $56 a$ & 43 \\
\hline Washington Hawthorn & $44 \mathrm{~b}$ & $35 b$ & $70 \mathrm{ab}$ & $98 \mathrm{a}$ & 62 \\
\hline Wild Plum & $83 a$ & $19 b$ & $43 \mathrm{ab}$ & $26 b$ & 43 \\
\hline Average Survival & $48 \mathrm{a}$ & $24 b$ & $42 \mathrm{a}$ & $42 \mathrm{a}$ & 39 \\
\hline
\end{tabular}

${ }^{1}$ Means for species survival with the same letter are not significantly different (within rows) at $\mathrm{p} \leq 0.05$. Where there are no letters, no significant difference in survival across sites. 


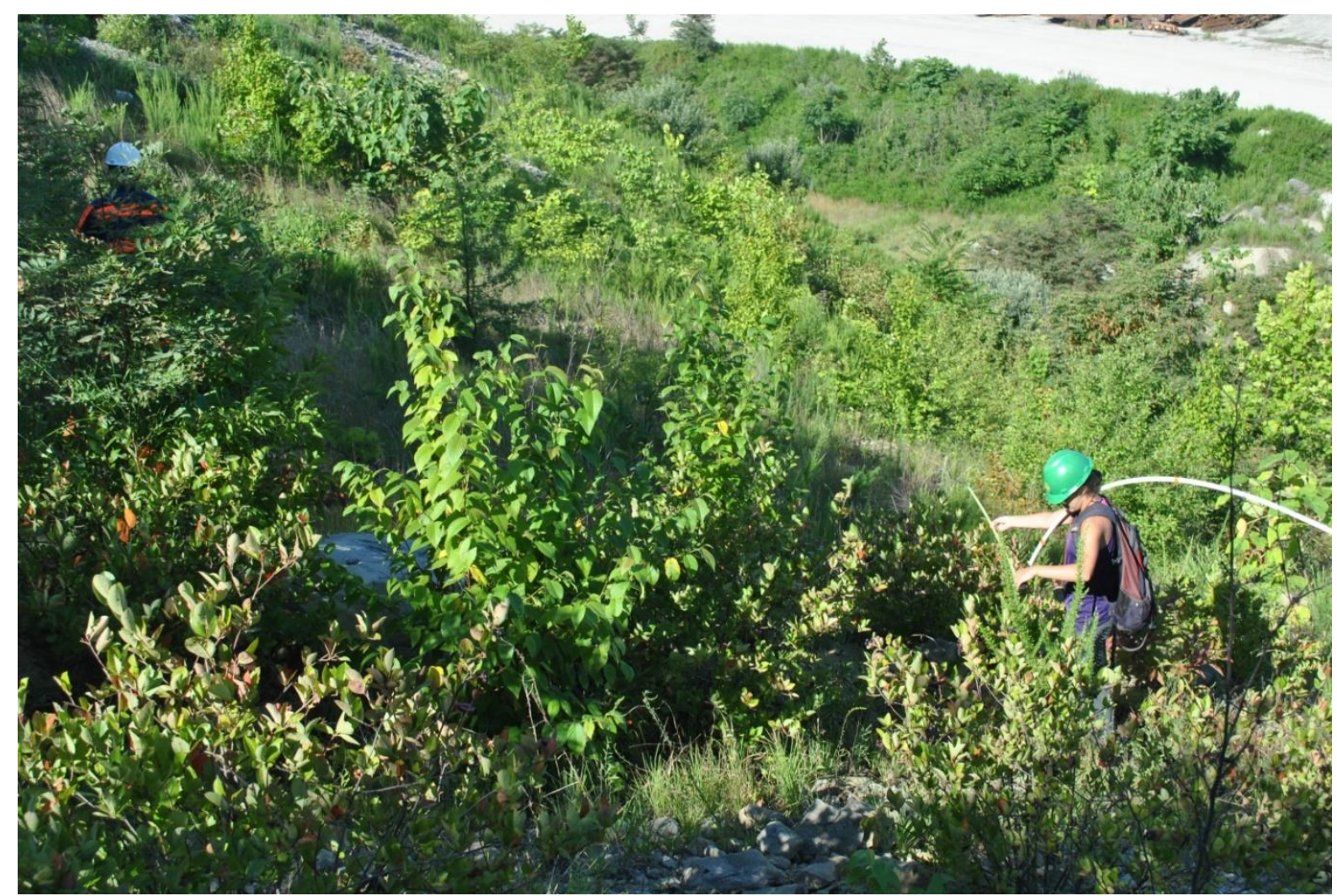

Picture 1. Serviceberry (foreground) and black chokeberry (background) at Elk Run showing good growth after 7 growing seasons.

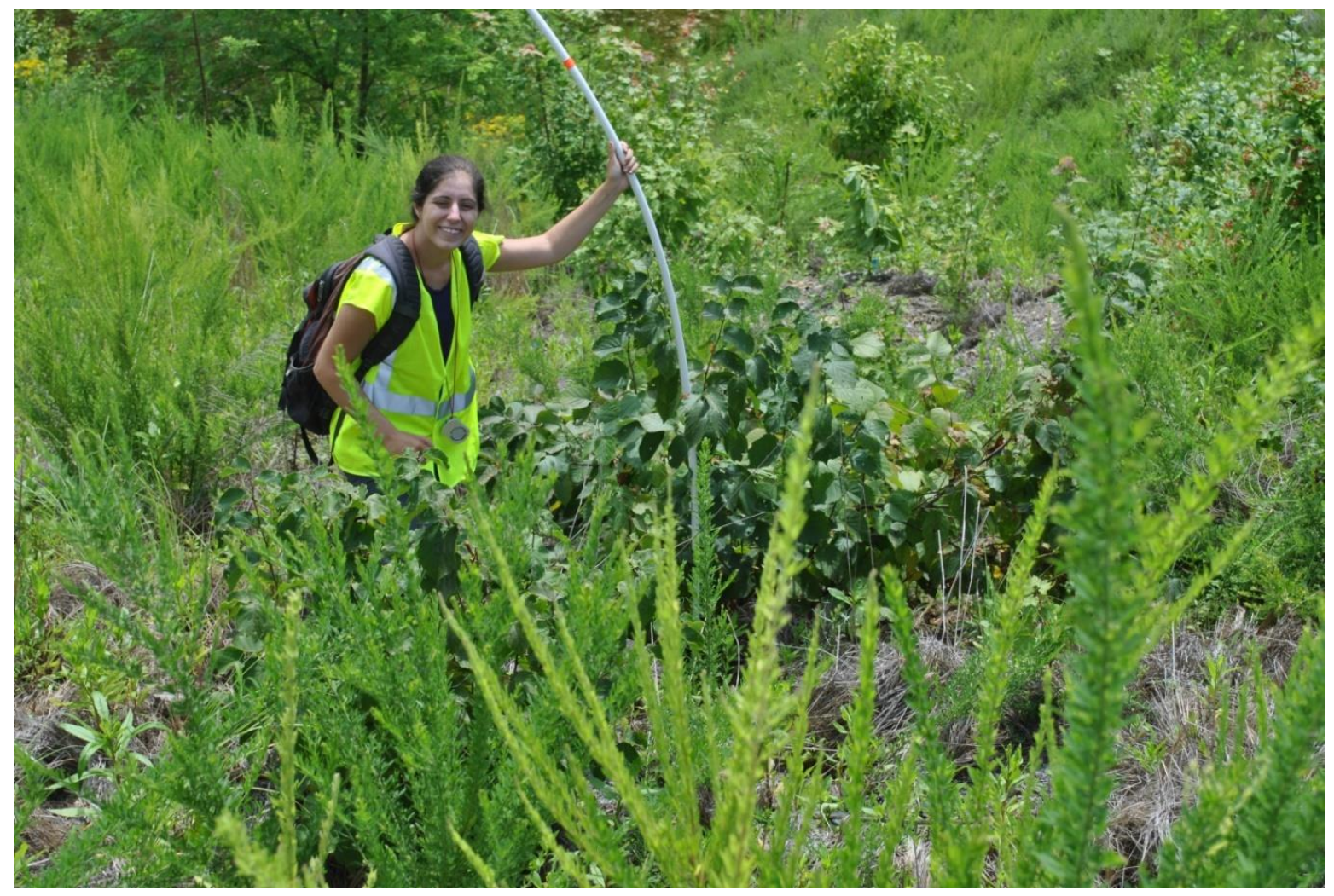

Picture 2. Good growth of hazelnut at Fola. 


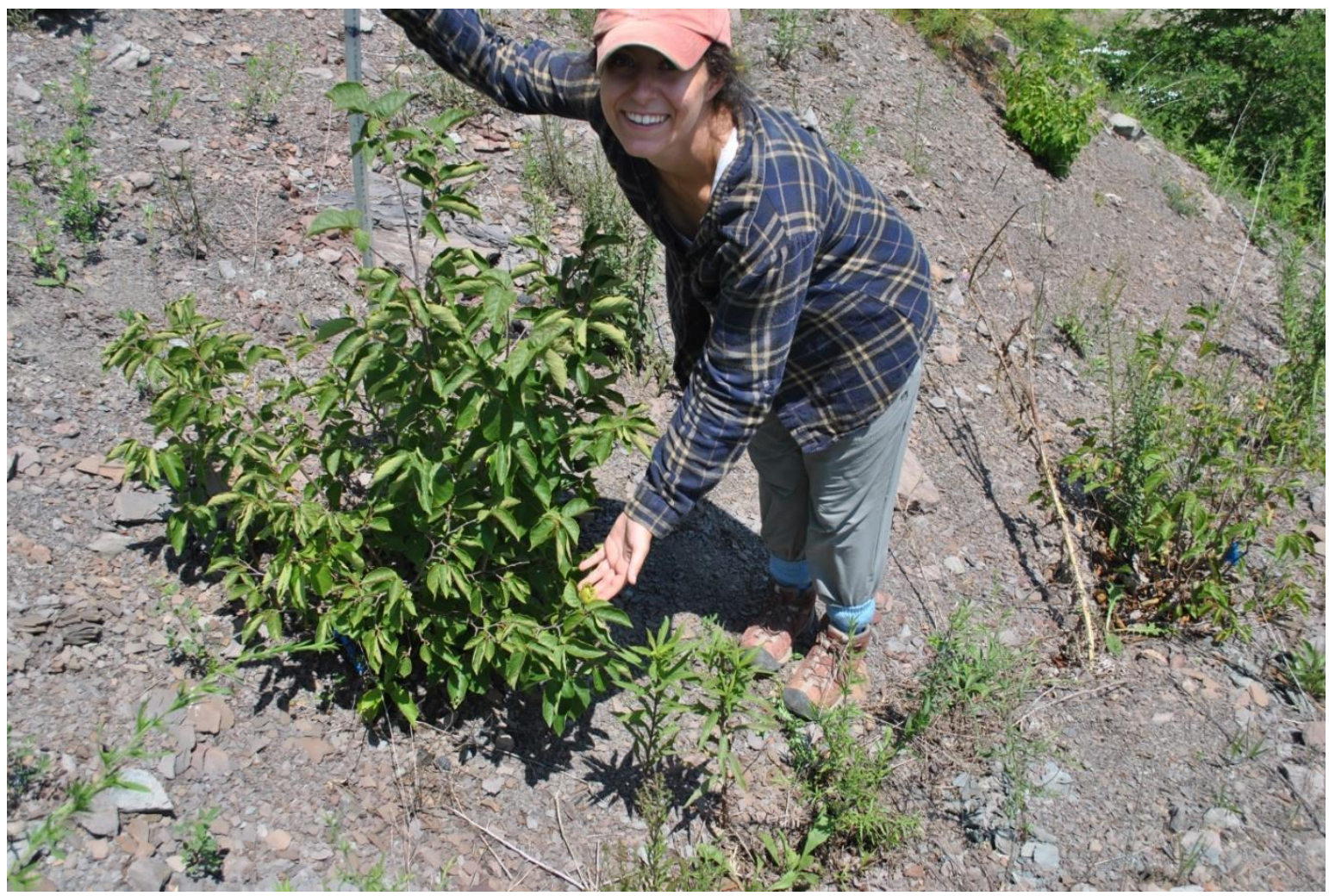

Picture 3. Nannyberry at Birch River. Herbaceous groundcover was sparse at Birch River.

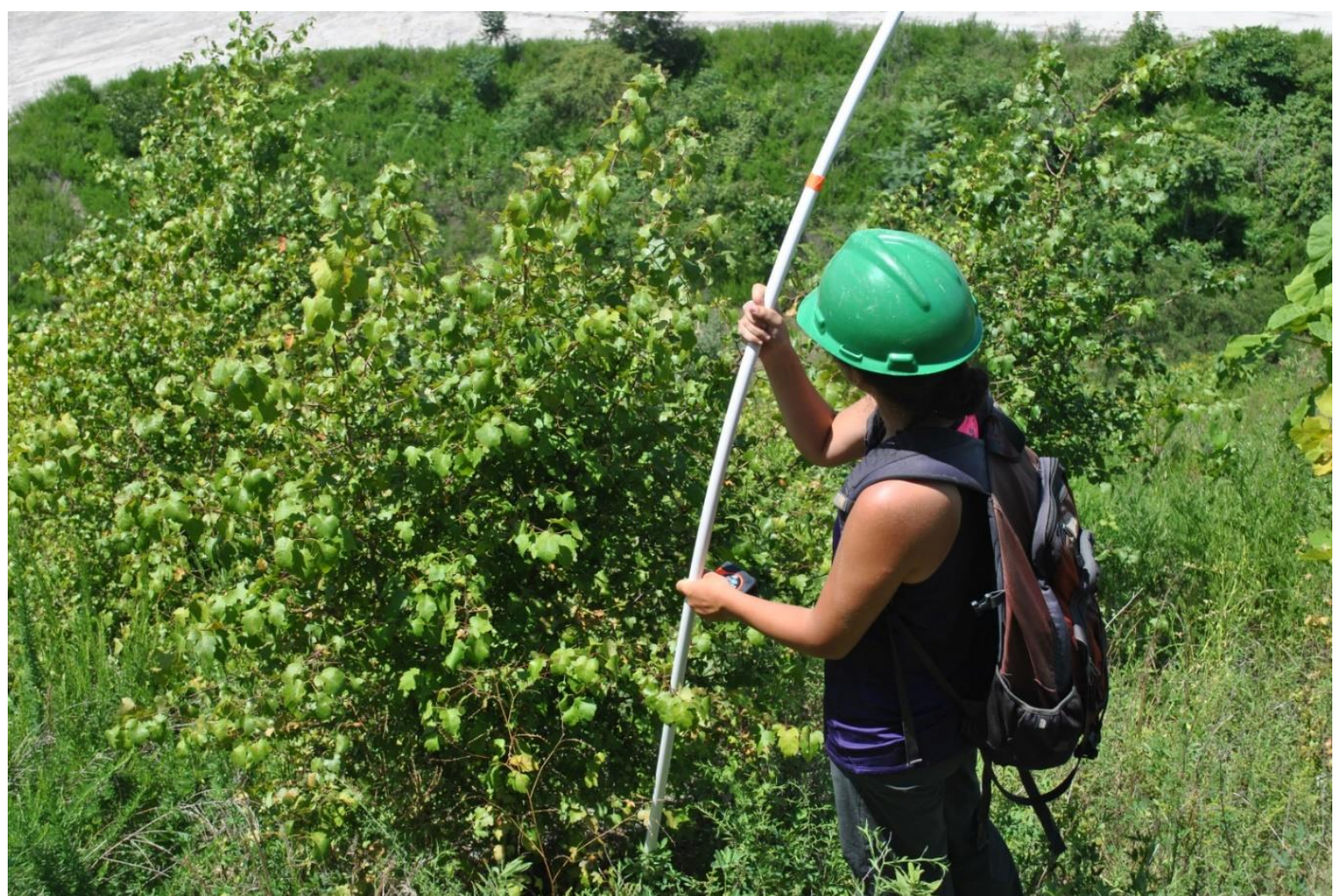

Picture 4. Washington hawthorn growing at Elk Run. Some trees were over $2 \mathrm{~m}$ tall. 


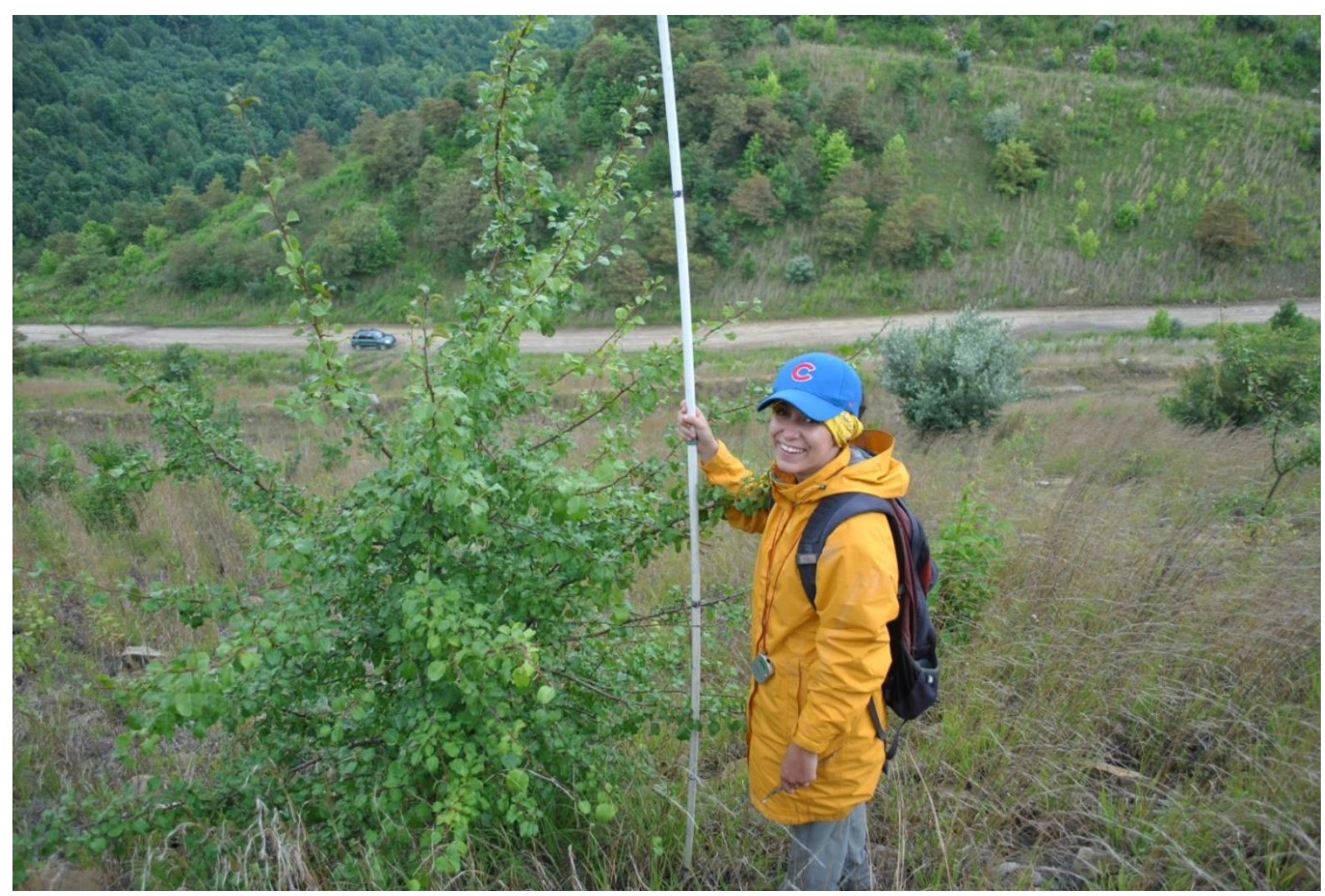

Picture 5. Washington hawthorn at Hobet.

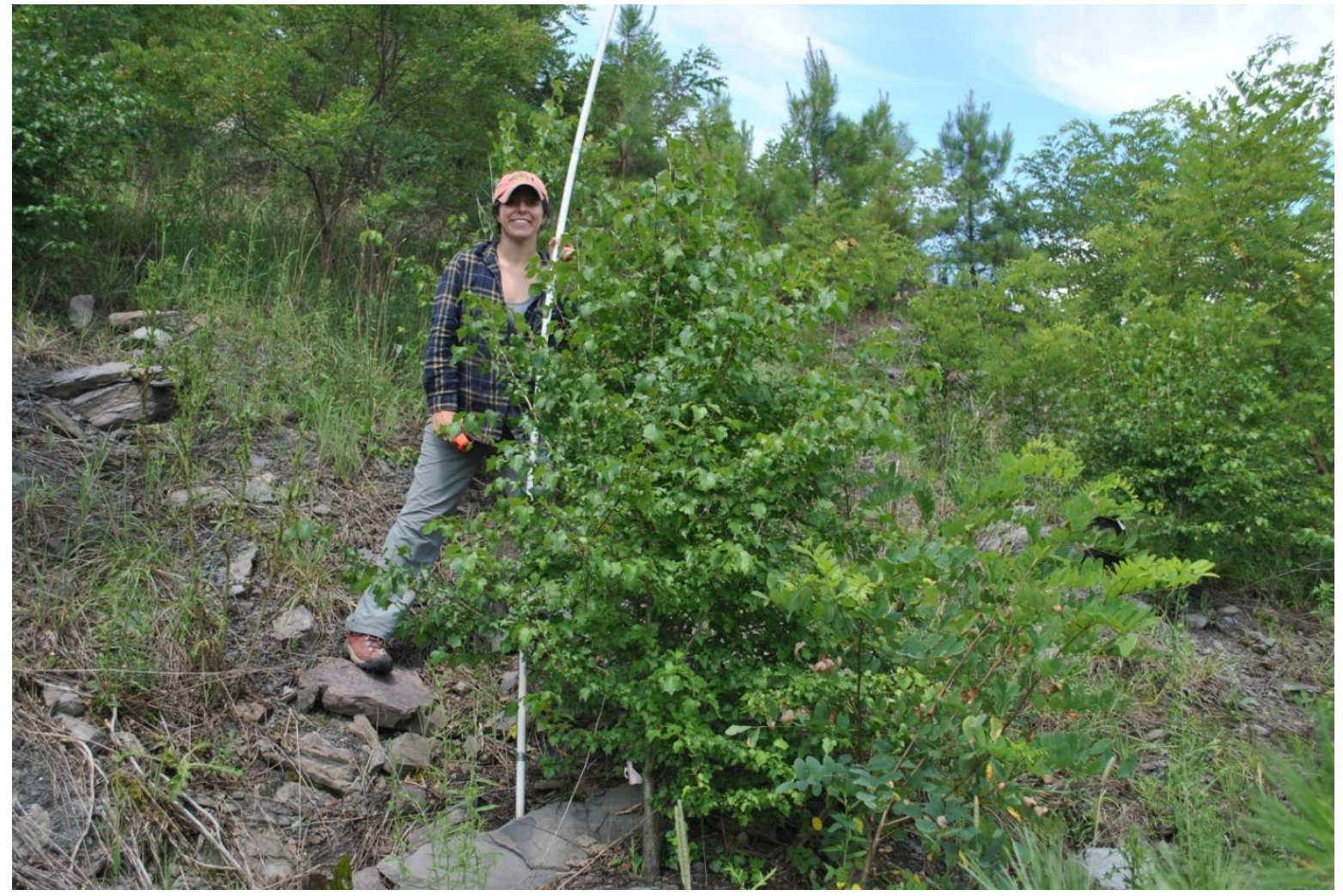

Picture 6. Washington hawthorn at Birch River. 
Significant differences between survival of individual species among sites was found for American crabapple, flowering dogwood, pawpaw, and serviceberry at Birch River. Significant differences in survival percentage was found for choke cherry, common pear, eastern redbud, elderberry, persimmon, and red mulberry at Hobet. Survival of wild plum was significantly higher at Elk Run than the other sites. Black cherry was the only species included in the study that did not show significant differences in survival percentages among sites.

Height of each individual tree/shrub was also measured in 2015. Differences in height were assessed at the individual species level, but not averaged for all species and compared between sites because of the difference in growth forms of the included species. The two site groups, those planted in 2008 and those planted in 2010 were analyzed separately, due to the difference in time since planting.

For shrubs, significant differences were found for all species between the two sites Elk Run and Hobet (Table 10). Black chokeberry, gray dogwood, highbush cranberry, and nannyberry were significantly taller at Elk Run than Hobet. Fola had significantly greater heights for all species than Birch River except for blueberry and gray dogwood (Table 11). When the heights in this table were compared to those in Table 4, it is apparent that the shrub species were growing on the selected sites. The tallest shrub species included highbush cranberry, nannyberry, and black chokeberry. The shortest shrubs were blueberry and hazelnut. This is probably due to the varying growth forms that exist among different shrub species. Average heights for all seven species on all sites varied from 106 to $22 \mathrm{~cm}$. Comparing average heights one year after planting (Table 4) with average heights after several growing seasons (Tables 10 and 11), all of the shrub species showed some growth except for blueberry. 
Table 10. Height of shrub species on Elk Run and Hobet in 2015 after 7 growing seasons after planting (Elk Run and Hobet planted in 2008).

\begin{tabular}{|c|c|c|c|}
\hline & & \multicolumn{2}{|c|}{ Sites } \\
\hline Shrub Species & Elk Run & Hobet & Average \\
\hline & \multicolumn{3}{|c|}{--------------------cm----------------- } \\
\hline Black Chokeberry & $100 a^{1}$ & $20 \mathrm{~b}$ & 60 \\
\hline Blueberry & $21 b$ & $57 \mathrm{a}$ & 39 \\
\hline Gray Dogwood & $155 a$ & $11 b$ & 83 \\
\hline Hazelnut & N/A & N/A & N/A \\
\hline Highbush Cranberry & $217 \mathrm{a}$ & $26 b$ & 122 \\
\hline Nannyberry & $132 \mathrm{a}$ & $44 b$ & 88 \\
\hline
\end{tabular}

${ }^{1}$ Means for species survival with the same letter are not significantly different (within rows) at $\mathrm{p} \leq 0.05$. Where there are no letters, no significant difference in height across sites.

Table 11. Height of shrub species on Birch River and Fola in 2015 after 5 growing seasons after planting (Birch River and Fola planted in 2010).

\begin{tabular}{|l|c|c|c|}
\hline & \multicolumn{3}{|c|}{ Sites } \\
\hline Shrub Species & Birch River & Fola & Average \\
\hline Black Chokeberry & ---------------- \\
\hline Blueberry & $12 \mathrm{a}$ & $90 \mathrm{a}$ & 75 \\
\hline Gray Dogwood & 110 & 125 & 6 \\
\hline Hazelnut & $32 \mathrm{~b}$ & $55 \mathrm{a}$ & 44 \\
\hline Highbush Cranberry & $64 \mathrm{~b}$ & $81 \mathrm{a}$ & 73 \\
\hline Nannyberry & $54 \mathrm{~b}$ & $116 \mathrm{a}$ & 85 \\
\hline
\end{tabular}

${ }^{1}$ Means for species survival with the same letter are not significantly different (within rows) at $\mathrm{p} \leq 0.05$. Where there are no letters, no significant difference in height across sites.

As in survival, height of tree species was almost always greater on Elk Run than on Hobet (Table 12). Height comparisons within species between Birch River and Fola were not so onesided, with some being taller on Birch River and some on Fola (Table 13). When comparing the heights of trees when planted (Table 5) to heights in 2015 (Tables 12 and 13), most species exhibited growth, but flowering dogwood and pawpaw did not. Those that showed increases in average height included black cherry (63 to $110 \mathrm{~cm}$ ), elderberry (16 to $34 \mathrm{~cm}$ ), common pear (46 to $93 \mathrm{~cm}$; Picture 7), and Washington hawthorn $(56$ to $105 \mathrm{~cm})$. Those species that displayed smaller average height increases were American crabapple (22 to $44 \mathrm{~cm}$ ), common apple (46 to $61 \mathrm{~cm}$ ), wild plum (42 to $68 \mathrm{~cm}$ ), eastern redbud $(45$ to $65 \mathrm{~cm}$ ), and persimmon (34 to $55 \mathrm{~cm}$; Picture 8). Other species decreased in height overall due to poor growth and low survival percentages. These species included pawpaw (32 to $16 \mathrm{~cm})$ and flowering dogwood $(37$ to $13 \mathrm{~cm})$. 


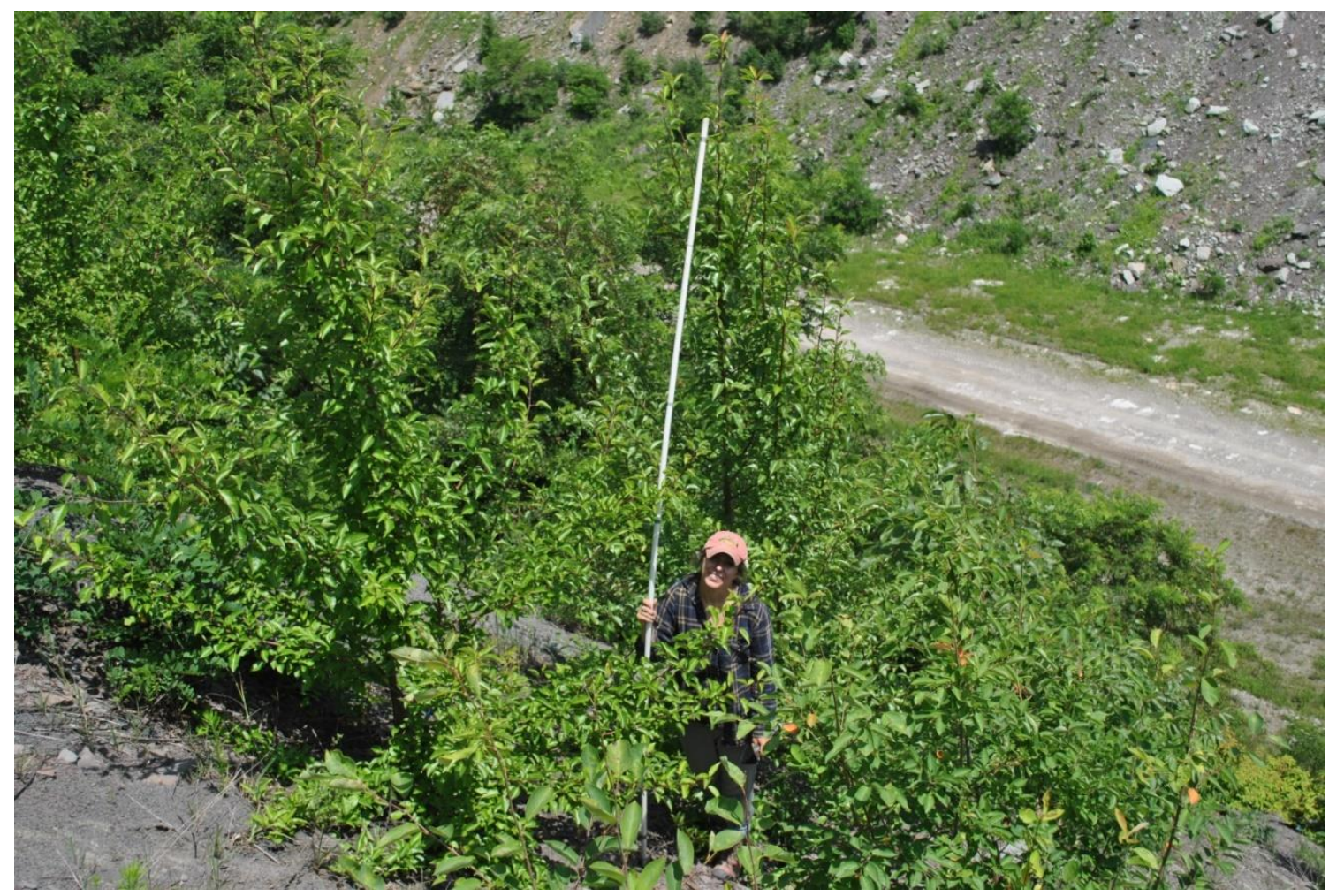

Picture 7. Common pear at Birch River. Some trees were over $3 \mathrm{~m}$ tall.

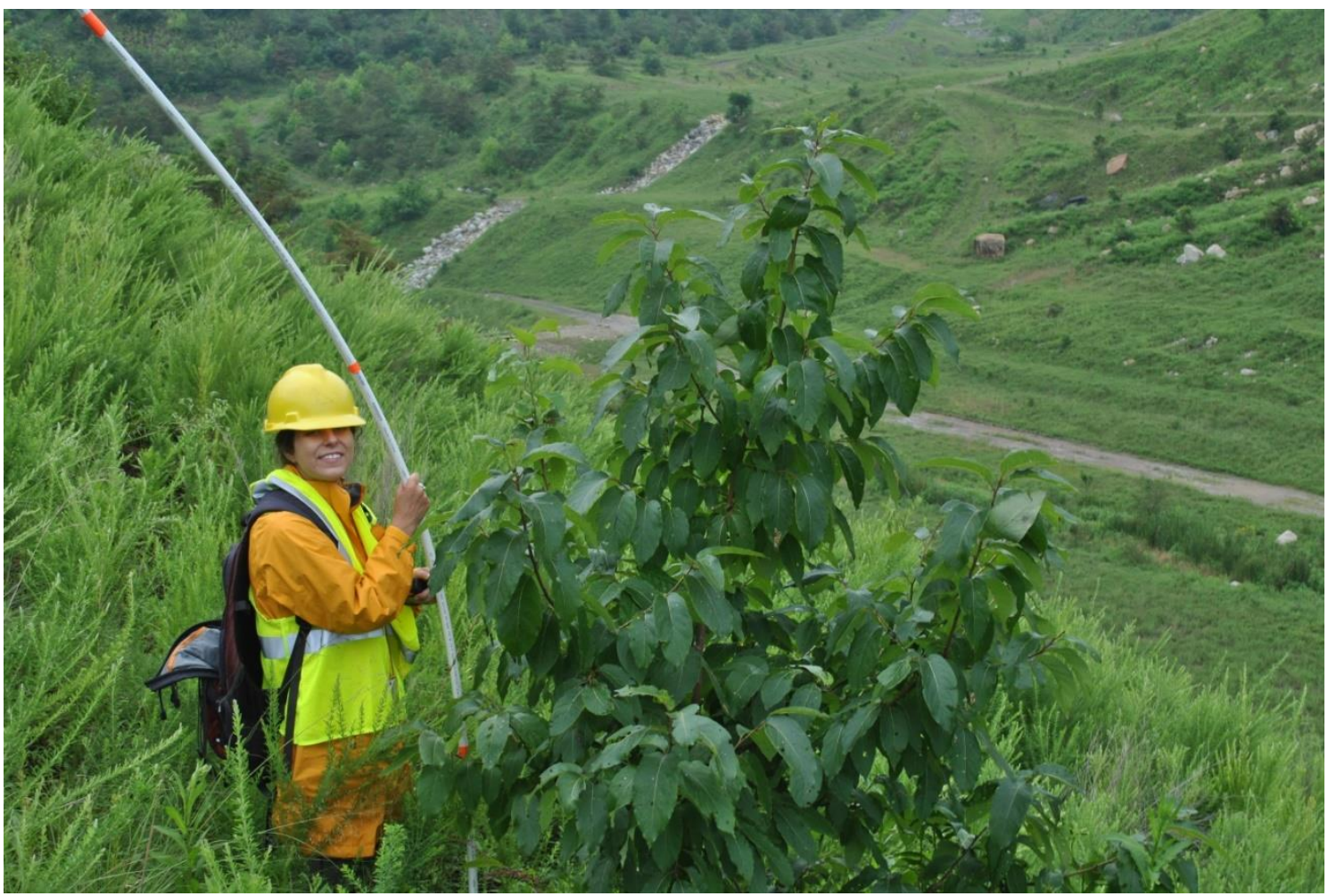

Picture 8. Persimmon on Fola showing good growth and health. 
Table 12. Height of all tree species on Elk Run and Hobet in 2015 after 7 growing seasons after planting (Elk Run and Hobet planted in 2008).

\begin{tabular}{|l|c|c|c|}
\hline & & \multicolumn{2}{|c|}{ Sites } \\
\hline Tree Species & Elk Run & Hobet & Average \\
\hline American Crabapple & ---------- & $\mathrm{cm}$ & ------------ \\
\hline Black Cherry & $72 \mathrm{a}^{1}$ & $29 \mathrm{~b}$ & 51 \\
\hline Choke Cherry & 110 & 82 & 96 \\
\hline Common Apple & $118 \mathrm{a}$ & $32 \mathrm{~b}$ & 75 \\
\hline Common Pear & 29 & 30 & 30 \\
\hline Eastern Redbud & $58 \mathrm{a}$ & $20 \mathrm{~b}$ & 39 \\
\hline Elderberry & $100 \mathrm{a}$ & $10 \mathrm{~b}$ & 55 \\
\hline Flowering Dogwood & 31 & 22 & 27 \\
\hline Pawpaw & 10 & 11 & 11 \\
\hline Persimmon & 0 & 0 & 0 \\
\hline Serviceberry & $101 \mathrm{a}$ & $12 \mathrm{~b}$ & 57 \\
\hline Red Mulberry & $157 \mathrm{a}$ & $48 \mathrm{~b}$ & 157 \\
\hline Washington Hawthorn & $91 \mathrm{a}$ & $10 \mathrm{~b}$ & 51 \\
\hline Wild Plum & $78 \mathrm{a}$ & $39 \mathrm{~b}$ & 59 \\
\hline
\end{tabular}

${ }^{1}$ Means for species survival with the same letter are not significantly different at $\mathrm{p} \leq 0.05$ (within rows). Where there are no letters, no significant difference in height across sites.

Table 13. Height of all tree species on Birch River and Fola in 2015 after 5 growing seasons after planting (Birch River and Fola planted in 2010).

\begin{tabular}{|l|c|c|c|}
\hline & \multicolumn{3}{|c|}{ Sites } \\
\hline Tree Species & Birch River & Fola & Average \\
\hline & -------------- \\
\hline American Crabapple & $19 \mathrm{~b}$ & $42 \mathrm{a}$ & 31 \\
\hline Black Cherry & 128 & 117 & 123 \\
\hline Choke Cherry & $74 \mathrm{a}$ & $38 \mathrm{~b}$ & 56 \\
\hline Common Apple & 93 & 99 & 96 \\
\hline Common Pear & $100 \mathrm{~b}$ & $163 \mathrm{a}$ & 132 \\
\hline Eastern Redbud & $51 \mathrm{~b}$ & $79 \mathrm{a}$ & 65 \\
\hline Elderberry & 39 & 40 & 40 \\
\hline Flowering Dogwood & 19 & 11 & 15 \\
\hline Pawpaw & 21 & 13 & 17 \\
\hline Persimmon & $64 \mathrm{a}$ & $42 \mathrm{~b}$ & 53 \\
\hline Serviceberry & 39 & 26 & 33 \\
\hline Red Mulberry & 104 & 103 & 104 \\
\hline Washington Hawthorn & $90 \mathrm{~b}$ & $181 \mathrm{a}$ & 136 \\
\hline Wild Plum & $73 \mathrm{a}$ & $38 \mathrm{~b}$ & 56 \\
\hline
\end{tabular}

${ }^{1}$ Means for species survival with the same letter are not significantly different at $p \leq 0.05$ (within rows). Where there are no letters, no significant difference in height across sites. 
Differences among the sites planted in 2008 and those planted in 2010 are possibly due to the different-sized planting stock used during those two separate years. Examples of this include common apple which averaged a height of $30 \mathrm{~cm}$ on the 2008 sites and $96 \mathrm{~cm}$ on the 2010 sites and serviceberry which averaged a height of $157 \mathrm{~cm}$ on the sites planted in 2008 and $33 \mathrm{~cm}$ on the sites planted in 2010 (Table 12 and 13).

Lastly, the effect of aspect on shrub species survival was tested in 2015. This data represented growth after 5 and 7 growing years (Table 14). The only significant difference found between the east- and west-facing aspects was for hazelnut. The west-facing aspect had higher overall survival at $44 \%$ than the east-facing blocks (39\%), but it was found not to be significantly different.

Table 14. Survival of all shrub species on all four sites in 2015 on east- and west-facing aspects after 7 and 5 growing seasons after planting (Elk Run and Hobet planted in 2008; Birch River and Fola planted in 2010).

\begin{tabular}{|l|c|c|c|}
\hline & \multicolumn{2}{|c|}{ Aspect } & \\
\hline Shrub Species & East & West & Average \\
\hline & ------- & ------ & \\
\hline Black Chokeberry & $35^{1}$ & 47 & 41 \\
\hline Blueberry & 34 & 49 & 42 \\
\hline Gray Dogwood & 33 & 51 & 42 \\
\hline Hazelnut & $62 \mathrm{a}$ & $21 \mathrm{~b}$ & 42 \\
\hline Highbush Cranberry & 35 & 49 & 42 \\
\hline Nannyberry & 36 & 48 & 42 \\
\hline Average Survival & 39 & 44 & 42 \\
\hline
\end{tabular}

${ }^{1}$ Means for species survival with the same letter are not significantly different at $\mathrm{p} \leq 0.05$ (within rows). Where there are no letters, no significant difference in survival across aspects.

For the tree species in this study, no significant differences were shown between the east- and west-facing aspects overall or within individual species (Table 15). The west-facing aspect had higher numerical overall survival (50\%) than the east-facing aspect (37\%), which was also the case for the shrub species. 
Table 15. Survival of all tree species on all four sites in 2015 on east and west facing aspects after 7 and 5 growing seasons after planting (Elk Run and Hobet planted in 2008; Birch River and Fola planted in 2010).

\begin{tabular}{|l|c|c|c|}
\hline & \multicolumn{2}{|c|}{ Aspect } & \\
\hline Tree Species & East & West & Average \\
\hline & \multicolumn{1}{|c}{------- \% -------- } \\
\hline American Crabapple & $36^{1}$ & 50 & 43 \\
\hline Black Cherry & 35 & 50 & 43 \\
\hline Choke Cherry & 35 & 49 & 42 \\
\hline Common Apple & 34 & 49 & 42 \\
\hline Common Pear & 36 & 49 & 43 \\
\hline Eastern Redbud & 37 & 51 & 44 \\
\hline Elderberry & 37 & 51 & 44 \\
\hline Flowering Dogwood & 36 & 48 & 42 \\
\hline Pawpaw & 38 & 50 & 44 \\
\hline Persimmon & 39 & 49 & 44 \\
\hline Serviceberry & 37 & 50 & 44 \\
\hline Red Mulberry & 40 & 50 & 45 \\
\hline Washington Hawthorn & 40 & 50 & 45 \\
\hline Wild Plum & 40 & 50 & 45 \\
\hline Average Survival & 37 & 50 & 44 \\
\hline
\end{tabular}

${ }^{1}$ Means for species survival with the same letter within rows are not significantly different at $p \leq 0.05$. Where there are no letters, no significant difference in survival across aspects.

$\underline{\text { Soils }}$

Elk Run and Fola had a lower average slope (around 15\%) compared to about $22 \%$ at Hobet and Birch River. It was observed that some soils were more compacted than others, and the differences were larger related to slope. Compaction was not measured on these sites with probes or meters, but appeared to be lower on those sites with steeper slopes based on walking and extracting soil samples. The assumed lower compaction at Hobet and Birch River could have influenced species growth. But as noted, Hobet generally had the lowest average heights for most of the shrub and tree species compared to the other sites, and Elk Run had the highest average heights.

The sites had different average soil pH values, which impacted the growth of the planted species. Birch River and Elk Run soils had the highest $\mathrm{pH}$ values (above 6.0), while Fola and Hobet soils were below 5.0 (Table 16). Soluble salts were very high at Fola, being three times 
higher than the average EC values at other sites. The low $\mathrm{pH}$ condition of the soil at Fola probably allowed for solubilization of elements, which contributed to the high EC levels at that site. Birch River had the lowest percent fines at 58\%, while the other sites had higher levels. A higher level of percent fines usually improves water relations and nutrient holding capacity. So the soil at Birch River probably had poorer water supply and fertility compared to the other sites.

Table 16. Average values for slope, $\mathrm{pH}$, electrical conductivity (EC), and \% fines for soils at each site measured in 2015.

\begin{tabular}{|l|c|c|c|c|}
\hline & \multicolumn{4}{|c|}{ Sites } \\
\hline Soil Properties & Elk Run & Hobet & Birch River & Fola \\
\hline Average slope $(\%)$ & $14 \mathrm{~b}^{1}$ & $22 \mathrm{a}$ & $23 \mathrm{a}$ & $16 \mathrm{~b}$ \\
\hline $\begin{array}{l}\text { Average } \mathrm{pH} \\
(\text { range })\end{array}$ & $6.4 \mathrm{~b}$ & $4.5 \mathrm{c}$ & $7.5 \mathrm{a}$ & $3.4 \mathrm{~d}$ \\
\hline $\mathrm{EC}(\mu \mathrm{S} / \mathrm{cm})$ & $85 \mathrm{~b}$ & $73 \mathrm{~b}$ & $84 \mathrm{~b}$ & $261 \mathrm{a}$ \\
\hline Fines $(\%)$ & $74 \mathrm{ab}$ & $82 \mathrm{a}$ & $58 \mathrm{~b}$ & $66 \mathrm{~b}$ \\
\hline
\end{tabular}

${ }^{1}$ Means for species survival with the same letter are not significantly different at $\mathrm{p}$ $\leq 0.05$ within the same row. Where there are no letters, no significant difference in that property across sites.

The site with the lowest $\mathrm{pH}$, low percent fines value, and highest EC was the Fola site, which should have made this site the poorest in terms of shrub and tree growth. But Fola generally had better average growth for planted species than Hobet. The Birch River site was found to have the highest $\mathrm{pH}$ value overall and the lowest percent fines. Birch River had a unique mine soil material with a mix of broken sandstone and Clarion shale materials, and was characterized by shale channers that were found in many places on the surface. This material also inhibited the amount of herbaceous competition growing on the site. The Hobet site had a low $\mathrm{pH}$ of 4.5, and the largest percentage of fines. Gully erosion was a common occurrence noted at this site due to the fine material in soils and steep slope. Elk Run had the largest $\mathrm{pH}$ range. This substrate was similar to that of Hobet, and gully erosion and bare soil conditions were common sights on the research blocks.

Species survival and growth were likely affected by these site conditions. For example, blueberry prefers acidic soils and will not thrive in alkaline conditions. Both conditions existed in this project, but the most acidic site, Fola, had the poorest blueberry survival with the highest blueberry survival at Hobet. The dry, upland conditions of the research blocks also affected the success of certain selected species including pawpaw and choke cherry, which generally prefer moist soil conditions. Additionally, growth of some of the selected species was affected by their 
degree of shade tolerance. Because this project was designed in a way that the planted species received direct solar radiation and had no canopy cover, species that require more shading did not thrive as well. And the east- or west-facing aspect at each site could also have impacted survival and growth of the planted species.

Site conditions examined in this study included $\mathrm{pH}$, percent fines, and electrical conductivity. The variation in these values across different sites gave some perspective on how differences in these site qualities affect growth and survival at a species specific level.

The Elk Run site had a moderate slope of $14 \%$ (significantly lower than Birch River and Hobet), a neutral pH of 6.4 (significantly higher than Hobet and Fola), and a low EC. It had the best survival percentages for choke cherry, nannyberry, and American crabapple, but the lowest survival percentage for flowering dogwood and a complete die out of pawpaw.

The Hobet mine site exhibited the worst overall survival percentages and growth. Hobet had a slope of $22 \%$, a low $\mathrm{pH}$ of 4.5 , low EC, and high fines of $74 \%$. These soil characteristics are perceived to be compatible with tree and shrub growth; however, Hobet had the lowest survival percentage for most of the species included in this study including red mulberry, black cherry, common apple, common pear, eastern redbud, gray dogwood, pawpaw, persimmon, Washington hawthorn, and wild plum. Like Elk Run, it also had a complete die out of pawpaw. But, this site had the highest survival percentage for blueberry and highbush cranberry.

The Birch River site had a slope of $23 \%$, the highest overall $\mathrm{pH}$ of 7.5 , low EC, and the lowest percent fines (58\%) of any site. Birch River also had the least amount of groundcover competition overall. This site showed the highest survival percentage for black cherry, common apple, common pear, eastern redbud, flowering dogwood, gray dogwood, pawpaw, persimmon, and Washington hawthorn. This same site exhibited the lowest survival percentages for hazelnut, American crabapple, and black cherry.

The Fola mine site possessed a moderate slope, the lowest $\mathrm{pH}$ range, and the highest EC value of any site included in the study. This site achieved the highest survival percentages for black chokeberry, hazelnut, Washington hawthorn, elderberry, common pear, and black cherry. Fola had the largest common pear trees of any site. Fola also showed the lowest survival percentage for blueberry, with a complete die out, and for choke cherry and serviceberry. 


\section{$\underline{\text { Conclusions }}$}

By performing a survey of tree survival and growth both the first year after planting and in the summer of 2015 either 5 or 7 years after planting, the success of the species could be evaluated and the species could be separated into the best performing and worst performing species based on average survival percentage. The best performing species in the study were Washington hawthorn, black cherry, nannyberry, and black chokeberry. The worst performing species included in the study were choke cherry, flowering dogwood, and pawpaw.

In future reclamation plantings, this study could aid in species selection. Planting some of the more successful species in this study including Washington hawthorn, black chokeberry, black cherry, gray dogwood, and nannyberry in future reclamation plantings would potentially encourage and accelerate ecological succession and benefit wildlife. Poor survival after 5 to 7 years of some of the species provided evidence that planting may not be practical and a waste of money and resources. Additionally, to increase the survival of the species that are more adapted to shade and other site conditions and to save money, it may be advisable to delay transplanting of these species or to allow native recruitment of these species after a canopy has been established from the planted trees. Species that prefer cove environments and rely heavily on moist soil conditions and shade, like pawpaw, should not be included in these plantings. Therefore, based on this study's survival and growth data on small trees and shrub plantings on surface mines, careful attention should be taken when selecting species and sites where such plantings should occur.

\section{Acknowledgments}

The authors thank Rick Williams, Jon Pomp, and Michael French of Williams Forestry. The idea for this project was developed by Rick Williams, and he and his workers located the sites and transplanted the more than 10,000 seedlings in this study. Jon Pomp and Michael French were responsible with others for monitoring the survival and growth during the first two years following planting. These early data were made available to the authors, which allowed a comparison between first year survival and growth data vs data collected in 2015. We also thank Keith O’Dell and Bill Young of Birch River; Kermit Fincham, Scott Perdue, and Cody Cooper of Elk Run; Dave Bays of Fola; Kenny Daniel of Hobet; and Mark McCoy of Nicholas for help in locating the plots and allowing access. 


\section{$\underline{\text { Literature Cited }}$}

Alday, J., V. Santana, R. Marrs, and C. Martinez-Ruiz. 2014. Shrub-induced understory vegetation changes in reclaimed mines sites. Ecol. Engineer. 73: 691-698. http://doi.org/10.1016/j.ecoleng.2014.09.079

Angel, P., V. Davis, J. Burger, D. Graves, and C. Zipper. 2005. The Appalachian Regional Reforestation Initiative. Forest Reclamation Advisory No. 1, December 2005.

Bise, J.B. 2013. Coal industry statistics. In: Modern American Coal Mining Methods and Applications. p. 1-23. Society for Mining, Metallurgy, and Exploration, Inc. Englewood, CO.

Bowling, K.C., F.W. Schaller, and P. Sutton. 1987. History of legislation for different states. p. 95-116. In Reclamation of Drastically Disturbed Lands. Am. Soc. Agron., Madison, Wisconsin.

Burger, J. and A. Fannon. 2009. Capability of reclaimed mined land for supporting reforestation with seven Appalachian hardwood species. Proceedings American Society of Mining and Reclamation 2009 pp 176-191. http://dx.doi.org/10.21000/JASMR09010176

Burger, J. 1999. Academic research perspective on experiences, trends, constraints, and needs related to reforestation of mined lands. p. 63-74. In Proceedings, Enhancements of Reforestation of Surface Coal Mines: Technical Interactive Forum, March 23-24, 1999, Fort Mitchell, KY.

Burger, J., D. Graves, P. Angel, V. Davis, and C. Zipper. 2005. The forestry reclamation approach. Appalachian Regional Reforestation Initiative. Forest Reclamation Advisory No. 2, December 2005.

Dallaire, K. and J. Skousen. 2015. Height of three hardwood species growing on mine sites reclaimed using the forestry reclamation approach compared to natural conditions. JASMR 4: 20-31. http://dx.doi.org/10.21000/JASMR15020020

Emerson, P., J. Skousen, and P. Ziemkiewicz. 2009. Survival and growth of hardwoods in brown vs gray sandstone on a surface mine in West Virginia. J. Environ. Qual. 38: 1821-1829. http://dx.doi.org/10.2134/jeq2008.0479

Gorman, J., J. Skousen, J. Sencindiver, and P. Ziemkiewicz. 2001. Forest productivity and minesoil development under a white pine plantation versus natural vegetation after 30 years. In Proceedings of the American Society of Mining and Reclamation, 2001 pp 103-111.

\section{http://dx.doi.org/10.21000/JASMR01010103}

MacDonald, E., S. Landhausser, J. Skousen, J. Franklin, J. Frouz, S. Hall, D. Jacobs, and S. Quideau. 2015. Forest restoration following surface mining disturbance: challenges and solutions. New Forests DOI 10.1007/s11056-015-9506-4. http://dx.doi.org/10.1007/s11056015-9506-4

NOAA National Centers for Environmental Information, State of the Climate: National Overview for Annual 2010, published online January 2011, retrieved on February 28, 2017 from http://www.ncdc.noaa.gov/sotc/national/201013.

NOAA National Centers for Environmental Information, State of the Climate: National Overview for Annual 2008, published online January 2009, retrieved on February 28, 2017 from http://www.ncdc.noaa.gov/sotc/national/200813. 
Plass, W.T. 2000. History of surface mining reclamation and associated legislation. p. 1-20. In: R.I. Barnhisel et al. (eds.) Reclamation of Drastically Disturbed Lands. Am. Soc. of Agron. Madison, WI.

R Development Core Team. 2016. Created by Ross Ihaka and Robert Gentleman at the University of Auckland, New Zealand. Available at www.r-project.org (Accessed 10 December 2016).

Statistical Analysis System. 2011. SAS/STAT systems for windows v.9.3. SAS Institute, Cary, NC.

Skousen, J. and C. Zipper. 2014. Post-mining policies and practices in the Eastern USA Coal Region. Intl. J. Coal Sci. Techn. 1: 135-151. http://dx.doi.org/10.1007/s40789-014-0021-6

Swanson, Mark E., J. Franklin, R. Beschta, C. Crisafulli, D. DellaSala, R. Hutto, D. Lindenmayer, and F. Swanson. 2010. The forgotten state of forest succession: early-succesional ecosystem on forest sites. Frontiers in Ecology and the Environment 9: 117-125.

http://onlinelibrary.wiley.com/doi/10.1890/090157/abstract

Torbert, J.L. and J.A. Burger. 2000. Forest land reclamation. p. 371-398. In R.I. Barnhisel et al. (eds) Reclamation of Drastically Disturbed Lands. Ameri Soc of Agron. Madison, WI.

Vogel, W., R. Thompson, and G. Wade. 1981. Success of trees and shrubs in an 18-year old planting on mine spoil. Res. Pap. NE-567. Broomall, PA: US Department of Agriculture, Forest Service, Northeastern Forest Experiment Station; 1985. http://www.fs.fed.us/ne/newtown_square/publications/research_papers/pdfs/scanned/ne_rp56 7p.pdf. Accessed 19 November 2016.

Zipper, C., J. Burger, C. Barton, and J. Skousen. 2013. Rebuilding soils for forest restoration on Appalachian mined lands. Soil Sci. Soc. Am. J. 77: 337-349.

http://dx.doi.org/10.2136/sssaj2012.0335

Zipper, C., J. Burger, J. Skousen, P. Angel, C. Barton, V. Davis, and J. Franklin. 2011. Restoring forests and associated ecosystem services on Appalachian coal surface mines. Environ. Management 47: 751-765. http://dx.doi.org/10.1007/s00267-011-9670-z 